\title{
PEMBUATAN BIOBRIKET DARI LIMBAH CANGKANG KAKAO
}

\section{The Making of Biobriquette from Cocoa Shell Waste}

\author{
Munas Martynis*, Elmi Sundari dan Ellyta Sari \\ Jurusan Teknik Kimia, Fakultas Teknologi Industri, Universitas Bung Hatta \\ JI. Gajah Mada No. 19, Olo Nanggalo Padang-25143 \\ Telp. (0751) 705425 fax (0751) 7051341 \\ *e-mail: munasmartynis@yahoo.com \\ Diterima : 19 Maret 2012, Revisi akhir: 1 Juni 2012
}

\begin{abstract}
ABSTRAK
Biobriket merupakan energi alternatif pengganti bahan bakar yang dihasilkan dari bahan-bahan organik atau limbah pertanian (biomassa) yang kurang termanfaatkan. Beberapa jenis limbah biomassa memiliki potensi yang cukup besar seperti limbah kayu, sekam padi, jerami, ampas tebu, cangkang sawit, dan sampah kota. Potensi lain yang belum tergarap adalah limbah cangkang kakao. Limbah-limbah tersebut apabila tidak dimanfaatkan maka akan menimbulkan bau yang tidak sedap dan dapat merusak ekosistem lingkungan. Penelitian ini bertujuan untuk melihat pengaruh variasi ukuran partikel dan bentuk biobriket terhadap kuat tekan biobriket yang dihasilkan, menganalisa mutu dan laju pembakaran bioriket. Pembuatan biobriket ini menggunakan bahan perekat tepung kanji sebanyak $50 \%$ dari berat biobriket, variasi ukuran partikel biobriket adalah 30 mesh dan 60 mesh, bentuk biobriket silinder berongga dan silinder pejal. Hasil penelitian menunjukkan bahwa biobriket yang dihasilkan telah memenuhi standar bahan bakar untuk rumah tangga. Biobriket yang paling bagus adalah biobriket dengan ukuran 30 mesh silinder berongga dan nilai kalor yang dihasilkan adalah lebih besar dari $4000 \mathrm{kal} / \mathrm{g}$. Berdasarkan uji pembakaran, biobriket yang diperoleh dapat digunakan sebagai bahan bakar.
\end{abstract}

Kata kunci : Biobriket, biomassa, limbah cangkang kakao

\section{ABSTRACT}

Biobriquette is an alternative energy as fuel substitute which is produced from organic materials or underutilized agricultural waste (biomass). Some types of biomass waste has considerable potential as wood waste, rice husks, straw, bagasse, palm shells, and municipal solid waste. Another untapped potential is the cocoa shell waste. These wastes are not used if it will cause a bad odor and may damage ecosystems. This study aims to see the effect of particle size variations and biobriquette shape to the biobriquette compressive strength produced, quality analysis, and combustion rate of biobriquette. The making of biobriquette used starch as adhesive as much as $50 \%$ of the biobriquette weight, variations of biobriquette particle size were 30 mesh and 60 mesh, the shape of biobriquette were hollow cylinder and solid cylinder. The results showed that biobriquette generated met the fuel standards for households. The best biobriquette was hollow cylinder biobriquette with the size of 30 mesh and the resulting calorific value was more than $4000 \mathrm{cal} / \mathrm{g}$. Based on burning test, biobriquette obtained could be used as fuel.

Key words: Biobriquette, biomass, cocoa shell waste 


\section{PENDAHULUAN}

Sumber energi tak terbarukan khususnya fosil (minyak dan gas) mempunyai peran penting dalam kehidupan manusia seharihari. Dengan semakin bertambahnya populasi penduduk menyebabkan kebutuhan akan bahan bakar pun meningkat sehingga dibutuhkan sumber alternatif yang lain. Salah satu energi terbarukan yang perlu mendapatkan perhatian untuk dikembangkan adalah biomassa. Biomassa adalah suatu limbah padat yang bisa dimanfaatkan lagi sebagai sumber bahan bakar (Syafi'i, 2003). Biomassa meliputi limbah kayu, limbah pertanian/perkebunan/hutan, komponen organik dari industri dan rumah tangga (Syafi'i, 2003).

Berdasarkan Statistik Energi Indonesia disebutkan bahwa potensi energi biomassa di Indonesia cukup besar, mencapai 434.008 GWh. Salah satu jenis potensi biomassa yang belum tergarap adalah limbah cangkang kakao. Limbah tersebut apabila tidak dimanfaatkan akan menimbulkan bau yang tidak sedap dan dapat merusak ekosistem lingkungan. Di Sumatera Barat potensi cangkang kakao yang dapat dijadikan bahan bakar 30.250 ton bahan kering per tahun (Statistik Dinas Perkebunan SUMBAR, 2009). Bahan bakar dari cangkang kakao ini cukup fleksibel untuk dapat dicetak dalam berbagai bentuk dan ukuran sesuai dengan kebutuhan. Nilai kalor yang terkandung dalam cangkang kakao telah memenuhi spesifikasi bahan bakar yaitu $4060 \mathrm{kal} / \mathrm{gram}$ (Statistik Energi Indonesia, 2004), dengan demikian cangkang kakao dapat dimanfaatkan sebagai bahan baku dalam pembuatan biobriket. Keunggulan biobriket dibandingkan arang biasa diantaranya menghasilkan panas pembakaran yang cukup tinggi, memiliki masa bakar yang jauh lebih lama, porositas dapat diatur untuk memudahkan pembakaran.

Teknologi pembuatan biobriket telah banyak dilakukan oleh peneliti sebelumnya dengan mengkomposisi berbagai macam bahan baku yang berasal dari bahan-bahan organik dan limbah pertanian. Namun biobriket yang dihasilkan memiliki kelemahan yaitu waktu penyalaan awal yang lama ( $\pm 10-15$ menit). Hasil penelitian terhadap biobriket yang dilakukan oleh Pramana
(2010) dengan menambahkan bahan kimia berupa $\mathrm{KMnO} 4$ yang berfungsi sebagai oksidator dapat mempersingkat waktu penyalaan awal dan menaikkan nilai kalor dengan penambahan 15\% KMnO4 ke dalam biobriket. Peneliti lain, Samsiro dan Saptoadi (2007) dalam penelitian terhadap biobriket bahan baku dari cangkang kakao dengan melihat pengaruh temperatur preheat terhadap laju pembakaran biobriket. Dari penelitian tersebut diperoleh bahwa kenaikan temperatur preheat dapat mempercepat laju pembakaran. Namun pada penelitian itu tidak dilakukan analisa mutu briket yang dihasilkan, disamping itu ukuran partikel juga tidak divariasikan, padahal ukuran partikel merupakan faktor yang mempengaruhi proses pembuatan biobriket dimana semakin kecil ukuran partikel semakin kuat briket yang dihasilkan namun porositasnya semakin rendah dan sebaliknya.

Penelitian ini bertujuan untuk melihat pengaruh variasi ukuran partikel dan bentuk biobriket terhadap mutu briket yang meliputi nilai kalor, kadar air, kuat tekan dan laju pembakaran dan kualitas nyala biobriket yang dihasilkan.

\section{METODOLOGI PENELITIAN}

\section{Bahan}

Bahan pembuatan briket adalah cangkang kakao, tepung kanji sebagai perekat dan air panas. Pemilihan tepung kanji sebagai perekat karena menghasilkan abu yang relative sedikit setelah pembakaran briket dan pada umumnya merupakan bahan pengikat yang efektif.

\section{Peralatan}

Peralatan yang digunakan adalah ayakan, gelas ukur, pengaduk, hot plate, baskom, cetakan biobriket, Oven, Bomb Calorimeter, Furnace, desikator, Strenght Test.

\section{Rancangan Penelitian}

Rancangan penelitian meliputi variasi ukuran partikel dan bentuk biobriket sebagai berikut: 
A1 = Briket ukuran 30 mesh silinder berongga

A2 = Briket ukuran 30 mesh silinder pejal

$\mathrm{B} 1$ = Briket ukuran 60 mesh silinder berongga

$\mathrm{B} 2=$ Briket ukuran 60 mesh silinder berongga

\section{Pelaksanaan Penelitian}

Pembuatan briket dapat dilakukan dengan metode tak terkarbonisasi dan terkarbonisasi. Pada penelitian ini digunakan metode tak terkarbonisasi.

Pembuatan briket diawali dengan persiapan bahan baku (cangkang kakao), membuat larutan perekat dan pembuatan briket.

1. Persiapan cangkang ini meliputi:

- Limbah cangkang kakao yang diperoleh dari perkebunan rakyat di Sumatra Barat dibersihkan dari kotoran-kotoran yang terikut.

- Dilakukan pengecilan ukuran.

- Dilakukan pengeringan dibawah sinar matahari sampai kadar air $12 \%$.

- Dilakukan penghalusan dengan alat penggiling

- Dilakukan pengayakan untuk ukuran partikel lolos ayakan 30 dan 60 mesh.

2. Pembuatan larutan kanji

- Tepung kanji sebanyak $1 \mathrm{~kg}$ dicampur dengan air mendidih sebanyak 1000 $\mathrm{ml}$, kemudian diaduk sampai terbentuk lem kanji yang siap digunakan.

3. Pembuatan briket

- Dilakukan pencampuran antara kulit kakao dan lem kanji dengan perbandingan $1: 1$ baik untuk ukuran partikel 30 dan 60 mesh.

- Dilakukan pengadukan sampai campuran homogen.

- Dimasukkan sampel ke dalam cetakan yang berbentuk silinder pejal dan silinder berongga dengan diameter $3,5 \mathrm{~cm}$ dan panjang $5 \mathrm{~cm}$ kemudian ditekan.

- Dikeluarkan briket dari cetakkan dan dilakukan pengeringan dibawah sinar matahari selama 2 hari dan pengeringan dengan menggunakan oven pada suhu $50^{\circ} \mathrm{C}$ selama 5 jam.
- Briket yang telah terbentuk, dilakukan analisa mutu briket yaitu nilai kalor, kadar air, kadar abu, kuat tekan, laju pembakaran.

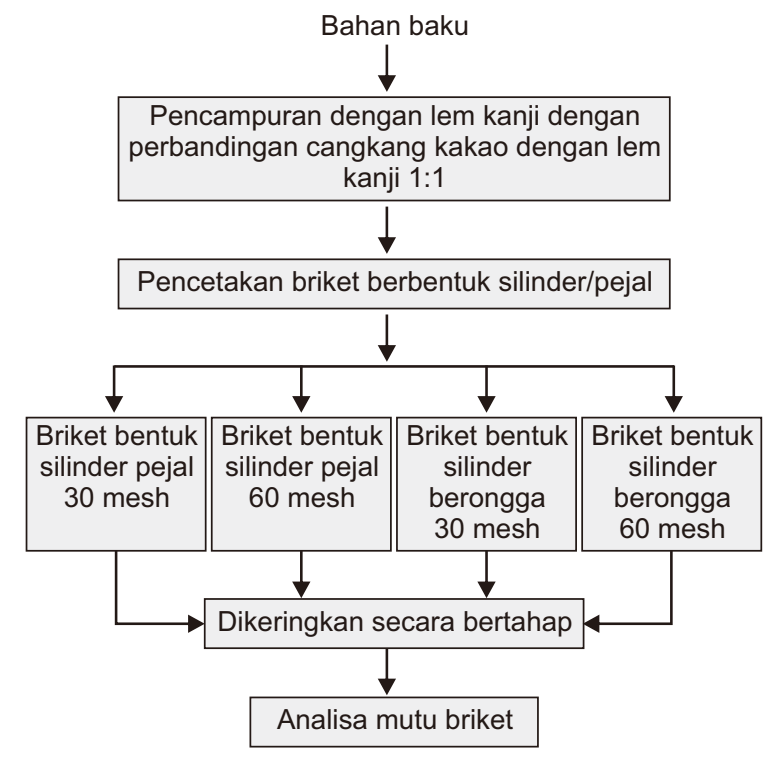

Gambar 1. Blok Diagram Pembuatan Biobriket

\section{Analisa Mutu}

\section{Nilai Kalor}

Nilai kalor dapat ditentukan dengan membakar sejumlah contoh dalam bomb calorimeter pada kondisi standar. Kalor yang dihasilkan dapat dihitung dari perubahan temperatur sebelum dan sesudah pembakaran dengan mengadakan beberapa koreksi.

Nilai kalor $=\frac{\mathrm{Na}(\mathrm{Ta}-\mathrm{To})-\mathrm{B}}{\text { Bobot contoh }} \mathrm{kalori} / \mathrm{gr}$

Dimana:

$\mathrm{Na}=$ Nilai air kalorimeter $=2459$ kalori

$\mathrm{Ta}=$ Temperatur akhir vessel

To $=$ Temperatur awal vessel

$\mathrm{B}=$ Jumlah nilai koreksi dari $\mathrm{HNO}_{3}, \mathrm{H}_{2} \mathrm{SO}_{4}$, dan kawat $\mathrm{Ni}-\mathrm{Cr}$

Koreksi $\mathrm{HNO}_{3}=(b-c) \times 1.5$ kalori

Koreksi $\mathrm{H}_{2} \mathrm{SO}_{4}=(\mathrm{a}-(\mathrm{b}-\mathrm{c}) \times 3.6$ kalori

Koreksi kawat $=$ panjang kawat $(\mathrm{cm}) \times 1.4$ kalori

Dimana:

$\mathrm{a}=$ Volume titran $\mathrm{Ba}(\mathrm{OH})_{2}$

$\mathrm{b}=$ Volume $\mathrm{Na}_{2} \mathrm{CO}_{3}$ yang ditambahkan ( 5 $\mathrm{ml}$ )

$\mathrm{c}=$ Volume titran $\mathrm{HCL}$

Panjang kawat $=10 \mathrm{~cm}$ 


\section{Kadar Air}

Kadar air ini merupakan kandungan air pada bahan bakar padat. Semakin besar kadar air yang terdapat pada bahan bakar padat maka nilai kalornya semakin kecil, begitu juga sebaliknya. Untuk menghitung kadar air yang terdapat pada briket dengan cara menguapkan air yang terdapat didalam briket tersebut sehingga tercapai keseimbangan kadar air dengan udara disekitarnya, dengan cara memanaskan contoh tersebut dalam oven dengan temperatur $110{ }^{\circ} \mathrm{C}$ selama 1 jam. Kemudian didinginkan dan dihitung kadar airnya sebagai berikut:

Kadar air $(\%)=\frac{(a-b)}{a} \times 100 \%$

Dimana :

$\mathrm{a}=$ berat sampel mula-mula (gram)

$b=$ berat sampel setelah dikeringkan (gram)

Dari tabel 2.3 kadar uap air yang diharapkan dari briket yang digunakan dalam rumah tangga adalah tidak boleh terlalu besar dari $7,5 \%$, karena nantinya akan mempengaruhi lamanya pembakaran.

\section{Kadar Abu}

Abu merupakan kotoran yang tidak akan terbakar. Kandungannya berkisar antara 5\% hingga 40\%. Kadar abu ini mempengaruhi efisiensi pembakaran. Menghitung kadar abu briket adalah dengan cara membakar briket tersebut didalam furnace pada suhu $900^{\circ} \mathrm{C}$ hingga semuanya terabukan. Kemudian abu yang didapat ditimbang dengan teliti.

Kadar abu $(\%)=\frac{\text { Berat abu }}{\text { Berat sampel }} \times 100 \%$

\section{Kuat Tekan}

Kuat tekan merupakan kemampuan briket menahan tekanan sampai retak (tidak mampu mempertahankan kondisi fisiknya) yang dilakukan dengan menggunakan alat strength test dengan satuan $\mathrm{kg} / \mathrm{cm}^{2}$.

\section{Laju pembakaran}

Laju pembakaran adalah besarnya massa terbakar briket per satuan waktu.

\section{HASIL DAN PEMBAHASAN}

Briket yang dihasilkan pada penelitian ini adalah jenis silinder berongga dan silinder pejal. Bentuk briket dapat dilihat pada Gambar 2 dan 3.

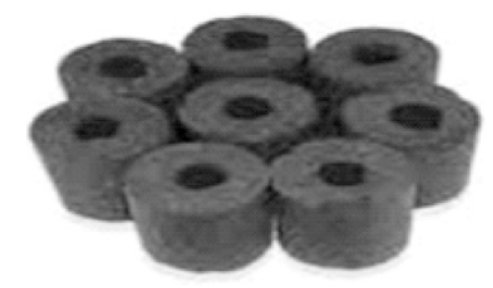

Gambar 2. Briket bentuk silinder berongga

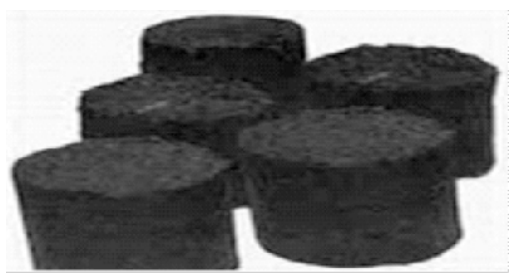

Gambar 3. Briket bentuk silinder pejal

Briket Bentuk silinder ini digunakan untuk kalangan Industri kecil atau menengah.

Data hasil pengamatan dapat dilihat pada Tabel 1. Standar mutu dan karakteristik pembuatan briket untuk rumah tangga Indonesia dapat dilihat dari Tabel 2

Tabel 1. Data hasil pengamatan

\begin{tabular}{|c|c|c|c|c|c|}
\hline \multirow{2}{*}{$\begin{array}{l}\text { Jenis } \\
\text { Briket }\end{array}$} & \multicolumn{5}{|c|}{ Parameter Output } \\
\hline & $\begin{array}{l}\text { Kadar } \\
\text { Air (\%) }\end{array}$ & $\begin{array}{l}\text { Kadar } \\
\text { Abu } \\
(\%)\end{array}$ & $\begin{array}{l}\text { Nilai } \\
\text { Kalor } \\
\text { (cal/gr) }\end{array}$ & $\begin{array}{l}\text { Kuat } \\
\text { Tekan } \\
(\mathbf{k g} / \mathrm{cm} \\
\text { ) }\end{array}$ & $\begin{array}{l}\text { Laju } \\
\text { pemba } \\
\text { karan } \\
\text { (gr/mn } \\
\text { it) }\end{array}$ \\
\hline $\mathrm{A}_{1}$ & 5,63 & 1,15 & 4395,67 & 11,02 & 0,625 \\
\hline $\mathrm{A}_{2}$ & 7,12 & 0,98 & 4219,54 & 10,30 & 1,300 \\
\hline$\overline{B_{1}}$ & 6,85 & 1,61 & 4064,90 & 12,12 & 1,250 \\
\hline$\overline{B_{2}}$ & 8,73 & 0,55 & 4221,03 & 13,16 & 1,125 \\
\hline $\begin{array}{l}\text { Stand } \\
\text { ar } \\
\text { mutu }\end{array}$ & $<7.5$ & - & $>4000$ & $>25$ & - \\
\hline
\end{tabular}


Tabel2. Standar mutu dan karakteristik briket untuk rumah tangga di Indonesia

\begin{tabular}{|c|l|l|}
\hline No. & \multicolumn{1}{|c|}{ Parameter } & \multicolumn{1}{c|}{ Nilai } \\
\hline 1 & Kadar uap air & $<7,5 \%$ \\
\hline 2 & Kadar zat terbang & $8-15 \%$ \\
\hline 3 & Kadar belerang & $<1 \%$ \\
\hline 4 & Nilai kalor & $>4000 \mathrm{kal} / \mathrm{gram}$ \\
\hline 5 & Kuat tekan & $>25 \mathrm{~kg} / \mathrm{cm}^{2}$ \\
\hline
\end{tabular}

Sumber: Direktorat Jenderal Pertambangan Umum,1993

\section{Kadar Air}

Dari Gambar 4 terlihat, jika dibandingkan dengan spesifikasi bahan bakar padat yang dikeluarkan oleh Direktorat Jenderal Pertambangan Umum (1993), kadar air biobriket jenis silinder berongga (A1 dan B1) telah memenuhi spesifikasi yaitu $5,63 \%$ dan $6,85 \%$ atau lebih kecil dari $7,5 \%$. Untuk briket jenis pejal (A2 dan B2) kadar airnya tidak memenuhi spesifikasi yaitu $7,12 \%$ dan $8,73 \%(>7,5 \%)$. Selain itu terlihat biobriket dengan ukuran partikel yang lebih besar (30 mesh) kadar airnya lebih rendah dibandingkan ukuran yang lebih halus (60 mesh).

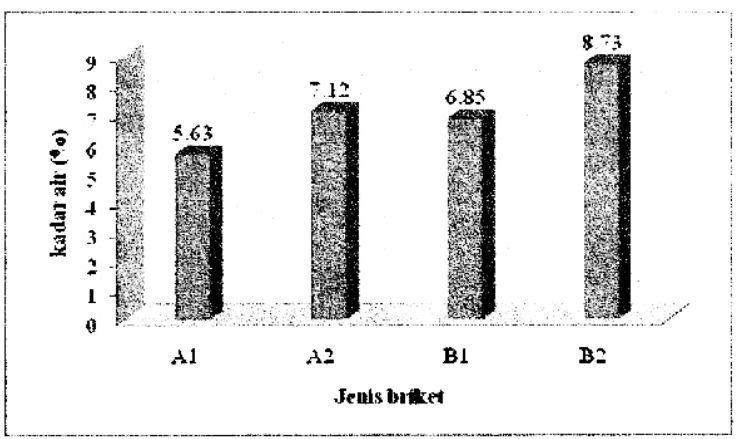

Gambar 4. Perbandingan kadar air tiap jenis biobriket

Hal ini dikarenakan biobriket bentuk silinder berongga mempunyai porositas yang lebih besar dibandingkan bentuk pejal sehingga penguapan air dari biobriket yang berongga lebih banyak dibandingkan bentuk pejal. Begitu juga dengan ukuran partikel, briket dengan ukuran partikel 30 mesh mempunyai porositas yang lebih besar dibandingkan ukuran partikel 60 mesh.

\section{Kadar Abu}

Abu atau disebut dengan bahan mineral yang terkandung dalam bahan bakar padat yang merupakan bahan yang tidak dapat terbakar setelah proses pembakaran. Abu adalah bahan yang tersisa apabila bahan bakar padat (kayu) dipanaskan hingga berat konstan (Earl, 1974).

Gambar 5 menunjukkan bahwa jenis biobriket dengan ukuran 60 mesh berbentuk silinder berongga mempunyai kadar abu yang paling tinggi yaitu sebesar $1.61 \%$ sedangkan biobriket dengan ukuran 60 mesh berbentuk silinder pejal mempunyai kadar abu terendah dibandingkan dengan jenis biobriket yang lain yaitu sebesar $0.55 \%$.

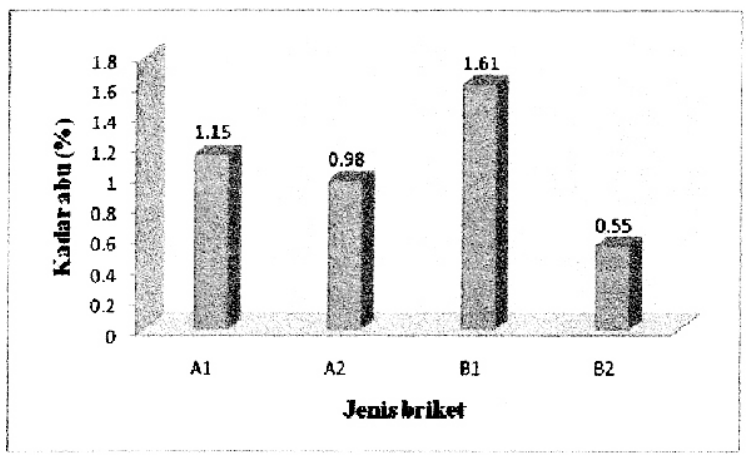

Gambar5. Perbandingan kadar abu tiap jenis biobriket

Hasil yang diperoleh berbanding terbalik dengan Sulistyanto A. (2006), yang menyatakan dengan partikel yang lebih kecil ukurannya, maka suatu bahan bakar padat akan lebih cepat terbakar. Hal ini diduga pada proses pencampuran biobriket $B_{1}$ kadar bahan perekat dengan bahan baku tidak homogen sehingga pada proses pembakarannya bahan perekat terbakar menjadiabu.

\section{Kuat Tekan}

Berdasarkan hasil penelitian yang ditampilkan pada Gambar 6. dapat terlihat bahwa secara umum nilai kuat tekan yang diperoleh tidak memenuhi standar kualitas biobriket untuk rumah tangga yaitu lebih besar dari $25 \mathrm{~kg} / \mathrm{cm}^{2}$. 


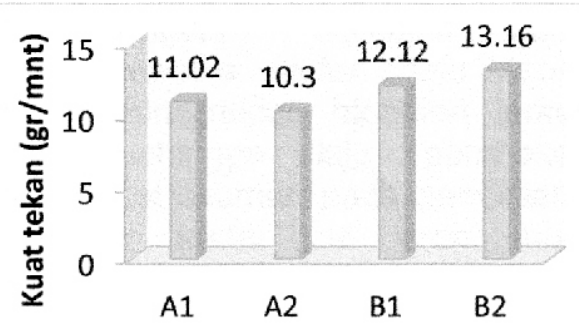

Jenis briket

Gambar 6. Perbandingan kuat tekan setiap jenis biobriket

Hal ini disebabkan oleh pengaruh alat pencetakan yang digunakan bukan alat khusus untuk pengepresan, tetapi alat cetakan yang terbuat dari kayu. Nilai kuat tekan yang paling besar adalah biobriket $\mathrm{B}_{2}$ yaitu biobriket ukuran 60 mesh silinder pejal sedangkan nilai kuat tekan yang paling kecil adalah bioriket $A_{2}$ yaitu biobriket ukuran 30 mesh silinder pejal. Hal ini disebabkan karena pengaruh komposisi ukuran partikel dimana semakin halus ukuran partikel maka biobriket yang dihasilkan semakin kuat.

\section{Nilai Kalor}

Nilai kalor yang dihasilkan pada penelitian (Gambar 7) secara umum telah memenuhi spesifikasi bahan bakar untuk skala rumah tangga ( $>4.000 \mathrm{kal} / \mathrm{gr}$ )

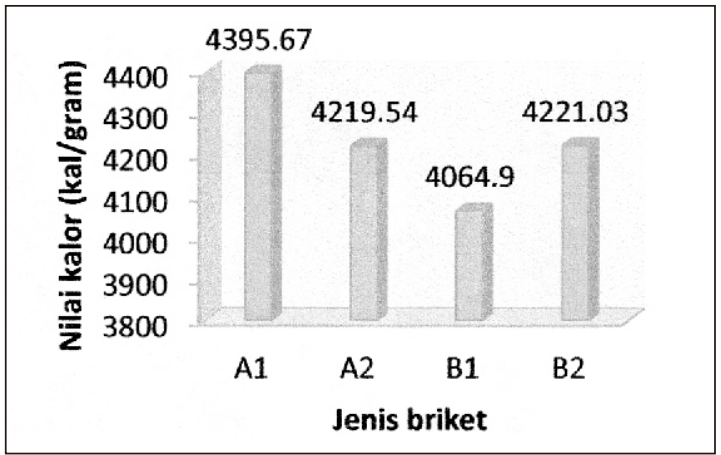

Gambar 7. Perbandingan nilai kalor tiap jenis biobriket

Nilai kalor yang terbesar terdapat pada biobriket ukuran 30 mesh silinder berongga, sedangkan nilai kalor yang paling kecil adalah biobriket ukuran 60 mesh silinder berongga. Berdasarkan Pramana dkk (2010) nilai kalor ini dipengaruhi oleh kadar air, semakin kecil kadar air dalam biobriket maka nilai kalor yang diperoleh semakin besar. Untuk biobriket $A_{1}$ memiliki kadar air terendah karena memiliki rongga dan berukuran partikel lebih besar sehingga pada saat proses pengeringan kadar air dalam biobriket lebih mudah menguap. Faktor lain yang mempengaruhi nilai kalor adalah komposisi biobriket, namun pada penelitian ini tidak divariasikan komposisi biobriket.

\section{Laju Pembakaran}

Laju pembakaran adalah besarnya massa terbakar briket per satuan waktu. Laju pembakaran briket sangat erat kaitannya dengan laju pengurangan massa dan temperatur.

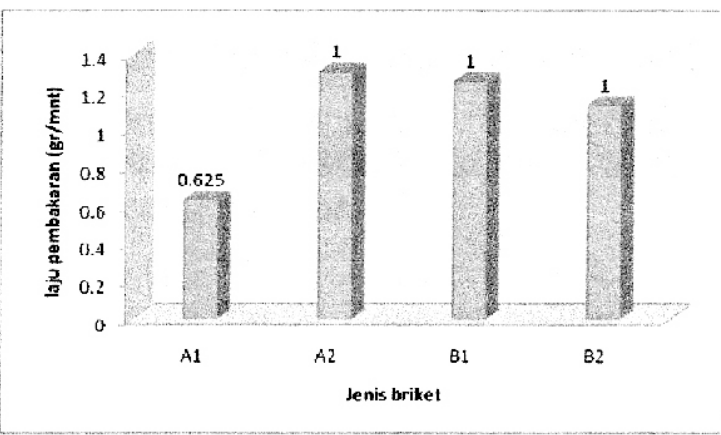

Gambar 8. Laju pembakaran tiap jenis biobriket

Gambar 8 memperlihatkan laju pembakaran yang tertinggi yaitu biobriket ukuran 30 mesh silinder pejal sedangkan laju pembakaran yang paling rendah yaitu biobriket ukuran 30 mesh silinder berongga. Hal ini sesuai dengan hasil penelitian Sulistyanto A. (2006) yang menyatakan bahwa salah satu faktor yang mempengaruhi proses pembakaran bahan bakar padat adalah ukuran partikel bahan bakar padat yang kecil. Dengan Partikel yang lebih kecil ukurannya, maka suatu bahan bakar padat akan lebih cepat terbakar. Kandungan nilai kalor yang tinggi pada suatu biobriket saat terjadinya proses pembakaran biobriket akan mempengaruhi pencapaian temperatur yang tinggi pula pada biobriket, namun pencapaian suhu optimumnya cukup lama. Laju pembakaran biobriket paling cepat adalah pada komposisi biomassa yang memiliki banyak kandungan volatile matter (zat-zat yang mudah menguap). Semakin 
banyak kandungan volatile matter suatu biobriket maka semakin mudah biobriket tersebut terbakar, sehingga laju pembakaran semakin cepat. Namun pada penelitian ini tidak diukur kadar zat yang mudah menguap.

\section{Karakteristik Pembakaran Briket yang Dihasilkan}

Karateristik pembakaran tiap-tiap jenis biobriket didapatkan hasil yang ditampilkan pada Tabel 3.

Tabel 3. Karateristik pembakaran biobriket.

\begin{tabular}{|c|c|c|c|c|}
\hline \multirow[b]{2}{*}{$\begin{array}{l}\text { Perla } \\
\text { kuan }\end{array}$} & \multicolumn{3}{|c|}{ Uji Nyala } & \multirow[b]{2}{*}{$\begin{array}{c}\text { Asap } \\
\text { Awal } \\
\text { pemba- } \\
\text { karan }\end{array}$} \\
\hline & $\begin{array}{l}\text { Waktu } \\
\text { Penya- } \\
\text { laan } \\
\text { (menit) }\end{array}$ & $\begin{array}{l}\text { Lama } \\
\text { nyala } \\
\text { api } \\
\text { (menit)* }\end{array}$ & $\begin{array}{l}\text { Kesta- } \\
\text { bilan } \\
\text { nyala }\end{array}$ & \\
\hline $\mathrm{A} 1$ & 8 & 35 & $\begin{array}{l}\text { Tdk } \\
\text { stabil }\end{array}$ & Ada \\
\hline $\mathrm{A} 2$ & 12 & 35 & $\begin{array}{l}\text { Tdk } \\
\text { stabil }\end{array}$ & Ada \\
\hline B1 & 14 & 40 & $\begin{array}{l}\text { Tdk } \\
\text { stabil }\end{array}$ & Ada \\
\hline $\mathrm{B} 2$ & 20 & 40 & $\begin{array}{l}\text { Tdk } \\
\text { stabil }\end{array}$ & Ada \\
\hline
\end{tabular}

Ket *). Lama nyala api sampai menjadi abu tidak stabil artinya tinggi nyala terkadang besar, terkadang kecil Nyala briket yang dihasilkan dapat dilihat pada Gambar 9.

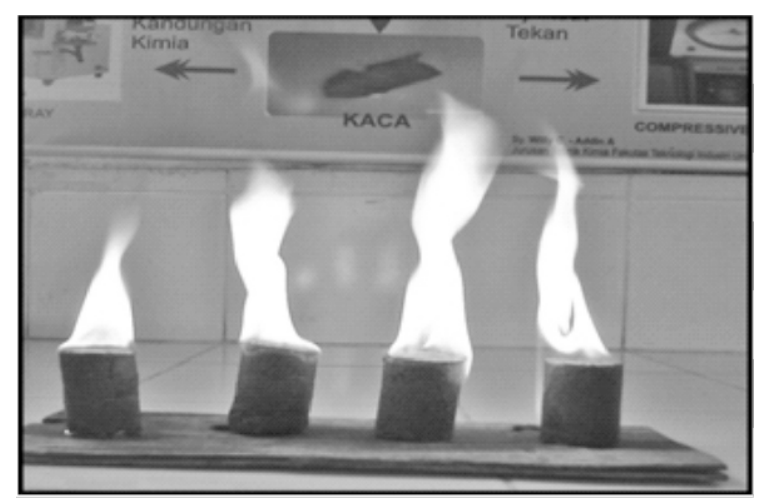

Gambar 9. Uji nyala biobriket

\section{KESIMPULAN DAN SARAN}

\section{Kesimpulan}

Jika ditinjau dari kadar air dan nilai kalor maka briket ukuran 30 mesh silinder berongga, dan briket ukuran 60 mesh silinder berongga lebih memenuhi standar mutu dan karakteristik briket untuk rumah tangga Indonesia.

\section{Saran}

Penelitian ini perlu dilanjutkan karena kuat tekan briket yang dihasilkan belum memenuhi standar mutu dan karakteristik briket untuk rumah tangga Indonesia.

\section{DAFTAR PUSTAKA}

Direktorat Jenderal Pertambangan Umum. 1993. Pedoman Pembuatan dan Pemanfaatan Batu Bara dan Bahan Bakar Padat Berbasis Batu Bara. Kementerian Energi dan Sumber Daya Mineral.

Dinas Perkebunan. 2009. Statistik Dinas Perkebunan Propinsi Sumatera Barat.

Departemen Energi dan Sumber Daya Mineral (DESDM). 2004. Statistik Energi Indonesia.

Earl, D.E. 1974. A report on Corcoal, Andre Meyer Researc Fellow. FAO. Rome

Pramana, A.N., Pradana, S.G. 2010, Pembuatan Biobriket dari Tempurung Kemiri sebagai Bahan Bakar Alternatif. Program Studi D3 Teknik Kimia Fakultas Teknologi Industri Institut Teknologi Sepuluh Nopember Surabaya 2010.

Sulistyanto, A. 2006. Karakteristik Pembakaran Biobriket Campuran Batubara dan Sabut Kelapa. Universitas Muhammadiyah, Surakarta.

Syafi'i, W. 2003. Hutan Sumber Energi Masa Depan. www.kompas.co.id. Harian kompas. Diakses 15April 2003.

Syamsiro, M., Harwin, S. 2007. Pembakaran Briket Biomassa Cangkang Kakao; Pengaruh Temperatur dan Preheat. Seminar Nasional Teknologi, Yogyakarta. 
